\title{
The effect of protein-calorie malnutrition on the composition of the human femur
}

\author{
BY J. W. T. DICKERSON \\ Department of Biochemistry, University of Surrey \\ AND P. M. V. JOHN \\ Infant Nutrition Research Division, Dunn Nutrition Laboratory, \\ University of Cambridge, and Medical Research Council \\ (Received 28 April r969-Accepted 26 fune 1969)
}

\begin{abstract}
I. A femur was analysed from each of the following malnourished children: five Turkish (4-7.5 months; marasmic), eight Jamaican (9-13 months; two marasmic, one marasmic with kwashiorkor, three with kwashiorkor, two 'malnourished') and two Ugandan ( 11 and I2 months; marasmic and with kwashiorkor respectively). These were matched with appropriate controls. Dry weight, fat, total nitrogen, collagen $\mathrm{N}$, calcium and phosphorus were determined, and values are presented for them in the bone, with and without epiphyses, and in the epiphyses and cortex.

2. The femurs of the Turkish children (4-7.5 months) showed greater deficits in length, $\mathrm{Ca}$ and $\mathrm{P}$ than did those of the Jamaican and Ugandan children (9-13 months). In both agegroups, regardless of the clinical condition, there was significantly less dry fat-free bone tissue than in control bones of similar ages. The concentration of fat in the bones was variable, but in the Turkish bones it was higher than in the controls.

3. When the epiphyses were excluded, the femurs of the Jamaican and Ugandan children with kwashiorkor contained a lower concentration of total $\mathrm{N}$ per $100 \mathrm{~g}$ fat-free solids than did those of children with marasmus.

4. The epiphyses of the malnourished children aged $4-7.5$ months contained lower concentrations of total $\mathrm{N}$, collagen $\mathrm{N}, \mathrm{Ca}$ and $\mathrm{P}$ than those of controls. In the older age-group the only significant difference was a lower level of $\mathrm{Ca}$.

5. The cortex of all the malnourished children had a similar composition to that of the controls.
\end{abstract}

Marasmus and kwashiorkor are probably best considered as the extremes of a spectrum of malnutrition (Jelliffe, 1959). The relative incidence and the ages at which they occur vary in different parts of the world (McLaren, 1966; Garrow, 1966). It is known that malnutrition either in man or animals, whether due primarily to deficiency of protein or of calories, results in a decreased rate of skeletal growth and of skeletal maturation (Berridge \& Prior, 1954; Jones \& Dean, 1956; 1959; Dickerson \& Widdowson, 1960; Dickerson \& McCance, 1961; Dickerson \& Hughes, 1968). In pigs and cockerels subjected to severe undernutrition from an early age the cortices of the long bones were greatly reduced in thickness and were hypercalcified (Dickerson \& McCance, 196I). No chemical analyses of bones from malnourished children appear to have been reported. This paper is concerned with the results of the analysis of femurs from children who died from severe malnutrition in Turkey, Jamaica and Uganda. 


\section{MATERIAL AND METHODS}

Femurs were obtained from five Turkish children aged $4-7 \cdot 5$ months, eight Jamaican children aged 9-I3 months and two Ugandan children aged II and I2 months. Table I summarizes the clinical diagnosis or dietary histories of the children. The Turkish children have all been classed as 'marasmic'. Of the Jamaican children, two were diagnosed as suffering from marasmus, one from marasmus with kwashiorkor, three from kwashiorkor and two from 'malnutrition'. One Ugandan child suffered from marasmus and one from kwashiorkor. The controls for the Turkish children were obtained from six British children aged 4-7 months who had died of an acute illness without skeletal involvement. Two of the controls for the Jamaican and Ugandan bones were obtained from well-nourished Jamaican children aged II and $\mathrm{r} 2$ months respectively, and four were obtained from British children aged 9-1 3 months who, like the ones in the younger age group, died of acute illnesses without skeletal involvement. All the British children died in the United Kingdom. The heights and weights of the control children were not available for comparison with those of the malnourished children. The composition of some of the control bones was included in the results of a previous study (Dickerson, $1962 a$ ).

\begin{tabular}{|c|c|c|c|}
\hline $\begin{array}{l}\text { Country of } \\
\text { origin* }\end{array}$ & $\begin{array}{c}\text { Age } \\
\text { (months) }\end{array}$ & $\begin{array}{c}\text { Clinical } \\
\text { diagnosis }\end{array}$ & Clinical details \\
\hline Turkey (5) & $4-7 \cdot 5$ & Marasmus & $\begin{array}{l}\text { Diarrhoea, vomiting, loss of weight } \\
\text { Weaned early and fed on cow's milk and } \\
\text { rice water for varying periods }\end{array}$ \\
\hline Jamaica (2) & 9 & Marasmus & $\begin{array}{l}\text { Gastroenteritis. Died } 15 \mathrm{~h} \text { and } 2 \text { days } \\
\text { respectively after admission }\end{array}$ \\
\hline Uganda (I) & I I & Marasmus & $\begin{array}{l}\text { Treated with high-protein diet but did not } \\
\text { Iespond well. Probably succumbed to } \\
\text { measles }\end{array}$ \\
\hline Jamaica (I) & 9 & $\begin{array}{l}\text { Marasmus and } \\
\text { kwashiorkor }\end{array}$ & Died within a few hours of admission \\
\hline Jamaica (3) & $9-13$ & Kwashiorkor & Died after being treated $0-7$ days \\
\hline Uganda (x) & I 2 & Kwashiorkor & $\begin{array}{l}\text { Very severe. Treatment with milk and } \\
\text { dextrose drip }\end{array}$ \\
\hline Jamaica (2) & 10,12 & 'Malnutrition' & $\begin{array}{l}\text { Kind of malnutrition unspecified. Both had } \\
\text { gastroenteritis and had probably been } \\
\text { losing weight for some time }\end{array}$ \\
\hline
\end{tabular}

* Figures in parentheses are the numbers of children.

After removal, the bones together with adherent muscle were sealed into polythene bags and stored at $-20^{\circ}$. They were transferred to England in a frozen state. Muscle, tendon attachments and periosteum were removed and the bones dissected into epiphyses, cortex and a 'remainder', which consisted of the two ends of the bone and the marrow removed from the samples of cortical bone. The dissection procedure and the subsequent analytical methods were those previously described (Dickerson \& Widdowson, I960; Dickerson, 1962 b). 
RESULTS

Table 2 shows the weights and heights of the malnourished children grouped in two age-groups. No differences in the Jamaican and Ugandan children could be attributed to the clinically diagnosed kind of malnutrition. Although there was a difference of 4 months in the mean ages of the Turkish children (6 months) and the Jamaican and Ugandan ones (10 months), the individual body-weights of the two groups overlapped. The overlap was more pronounced in the body length in which the means and ranges were almost identical. The height deficit was therefore somewhat greater in the older group.

Table 2. Weights and heights of malnourished children

(Values are means for the number of children shown; range shown in parentheses)

$\begin{array}{lcc}\text { No. } \ldots . . . \quad \ldots & 5 & \text { ro } \\ \text { Age (months) } & 6 & \text { 10 } \\ & (4-7 \cdot 5) & (9-13) \\ \text { Body-weight }(\mathrm{kg}) & 3 \cdot 33 & 4 \cdot 84 \\ & (2 \cdot 74-4 \cdot 53) & (3 \cdot 3-6 \cdot 65) \\ \text { Height }(\mathrm{cm}) & 6 \mathrm{r} & 60 \\ & (56-66) & (56-67) \\ \text { Body-weight as percentage of } & 44 & 5 \mathrm{I} \cdot 5 \\ \text { expected weight* } & (33-53) & (36-69) \\ \text { Height as percentage of ex- } & 89 & 82 \\ \text { pected height* } & (82-95) & (69-89) \\ \text { pected weights and heights taken from Tanner, Whitehouse \& Takaishi (Ig66). }\end{array}$

Table 3 sets out the length and composition of the femurs from the malnourished and control children. The bones from the Turkish children were shorter $(P<0.01)$, weighed less $(P<0.01)$, contained more fat per roog dry weight $(P<0.01)$ and less calcium and phosphorus per roog dry fat-free solids $(P<0.0 \mathrm{I})$ than the control bones of similar age. The concentration of total nitrogen in the bones from malnourished children was the same as in the controls and, although the mean value for the concentration of collagen $\mathbf{N}$ in bone was a little lower in the malnourished children, the difference was not significant. $\mathrm{Ca}: \mathrm{N}$ ratio in the malnourished bones was lower $(P<0.01)$ than in the controls.

A comparison of the two groups of control bones shows only slight and insignificant differences between them in most respects, including, surprisingly, the dry weight and length. The concentration of fat in the dry bone, however, was much lower in the younger group. Comparison of the composition of femurs from Jamaican children with clinical marasmus with those from children with clinical kwashiorkor shows no consistent differences between them. The bone from the Ugandan child with marasmus contained no measurable fat, whereas that from the Ugandan child with kwashiorkor contained $33.8 \mathrm{~g} / \mathrm{I} 00 \mathrm{~g}$ dry bone. The mean values for the different measurements in all the bones from the older age-group of malnourished children, regardless of clinical condition, are given in Table 3 . The bones from malnourished children weighed less than their controls $(P=0.05)$ but the difference was not as great as in the younger 


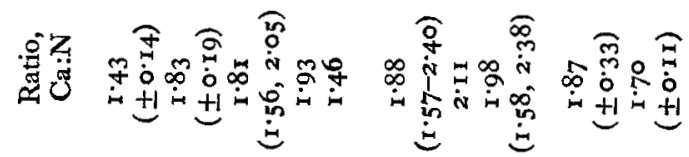

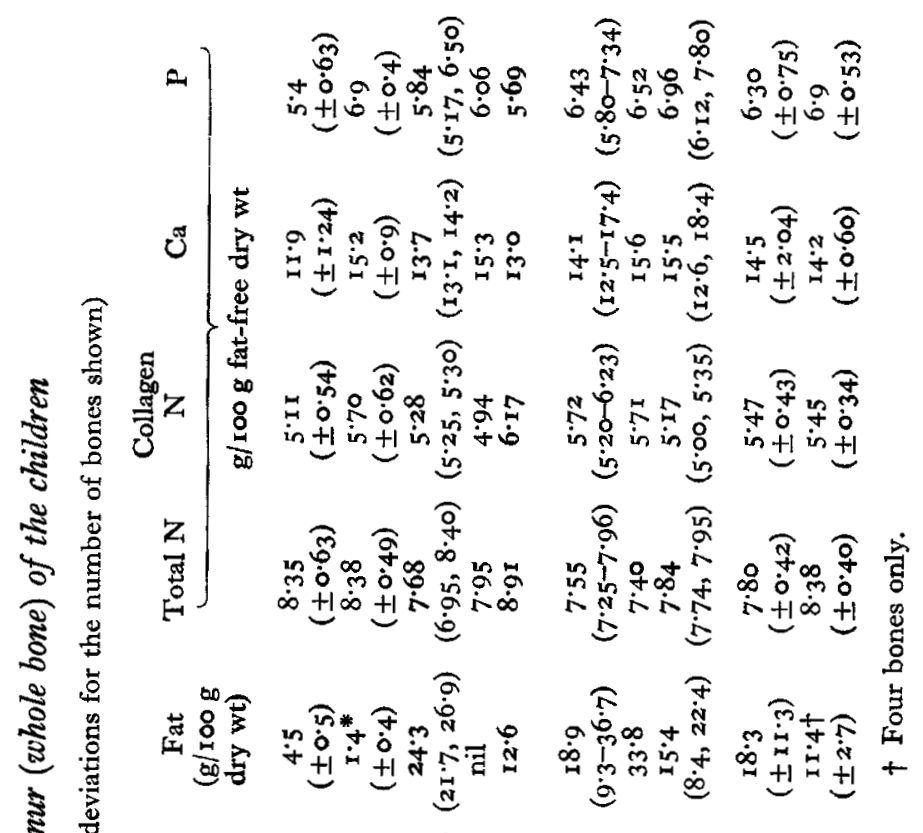

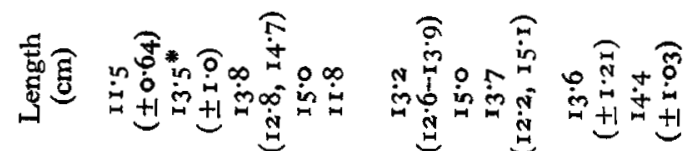

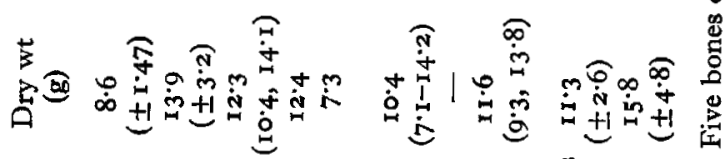

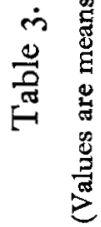

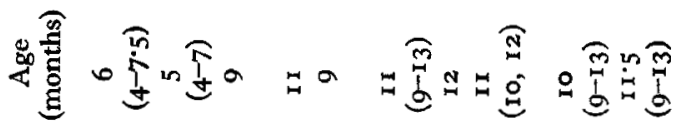

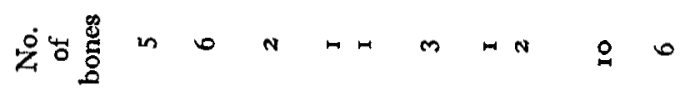

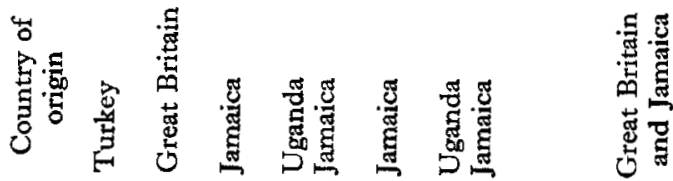


age-group. The differences in bone length and the composition of the dry fat-free solids were not significant. The percentage of fat in the dry bone was, on average, higher in all forms of malnutrition, but the individual values ranged from o to $36.7 \%$. There was no consistent relationship between the amount of fat in the bones and that in the livers.

The weight and composition of the femurs without the epiphyses have been calculated and the results are set out in Table 4. The fat-free dry weight of the bones from malnourished children in both age-groups was less than the control values. At 9-1 3 months there was no significant difference between the fat-free dry weight of bones from children with marasmus and those with kwashiorkor. The bones from the Turkish children contained lower concentrations of collagen $\mathrm{N}(P<0.01)$, Ca $(0.01<P<0.02), \mathrm{P}(0.01<P<0.02)$ and the $\mathrm{Ca}: \mathrm{N}$ ratio was also lower $(P<0.05)$ than those of their control group.

In the older age-group the comparison of bones from Jamaican and Ugandan children with kwashiorkor with those from children with marasmus showed that the former contained a lower concentration of total N $(P<0.05)$ but similar concentrations of collagen $\mathrm{N}, \mathrm{Ca}$ and $\mathrm{P}$. As a consequence of the lower value for total $\mathrm{N}$ the $\mathrm{Ca}: \mathrm{N}$ ratio in the bones from kwashiorkor cases was higher than in the marasmic cases $(0.02<P<0.05)$. There was a greater difference between the concentration of total bone $N$ in the kwashiorkor cases and that in the controls $(P<0.01)$ but there was no difference between the kwashiorkor cases and the controls in the concentration of collagen $\mathrm{N}, \mathrm{Ca}$ or $\mathrm{P}$ or in the $\mathrm{Ca}: \mathrm{N}$ ratio.

Table 5 shows the effect of malnutrition on the composition of the epiphyses. Since there were no differences in composition that could be attributed to the different forms of malnutrition in the older age-group the results for all the bones from malnourished children in the older age-group, as in the younger group, have been averaged and the mean values are shown in Table 5. The dry fat-free solids of the epiphyses of the bones in the younger malnourished group contained less total $\mathrm{N}(P<0.0 \mathrm{I})$ and less collagen $\mathrm{N}(P<0.00 \mathrm{I})$ than did those of the corresponding control bones. The mean values for the concentration of $\mathrm{Ca}$ and $\mathrm{P}$ in the bones from the younger malnourished children were also lower $(0.02<P<0.05)$ but the difference in the $\mathrm{Ca}: \mathrm{N}$ ratio was not significant. In the older age-group the concentration of $\mathrm{Ca}$ was lower $(P<0.05)$ but the differences in the other measurements were not significant.

Table 6 sets out the composition of the cortex of the bones grouped as in Table 5 . It shows that in all the measurements made the cortex of the malnourished bones had similar values to those of the corresponding controls.

\section{DISCUSSION}

The body-weights and heights of the malnourished children were less than those of British children of the same age well-nourished for the whole of their lives (Tanner, Whitehouse \& Takaishi, 1966). The femurs of the 4-7.5 month old malnourished children were smaller than those of the control children of similar age. The control bones for the older age-group were, however, of similar length to those from 


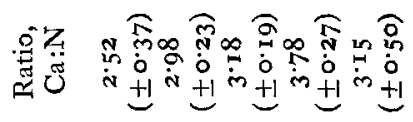

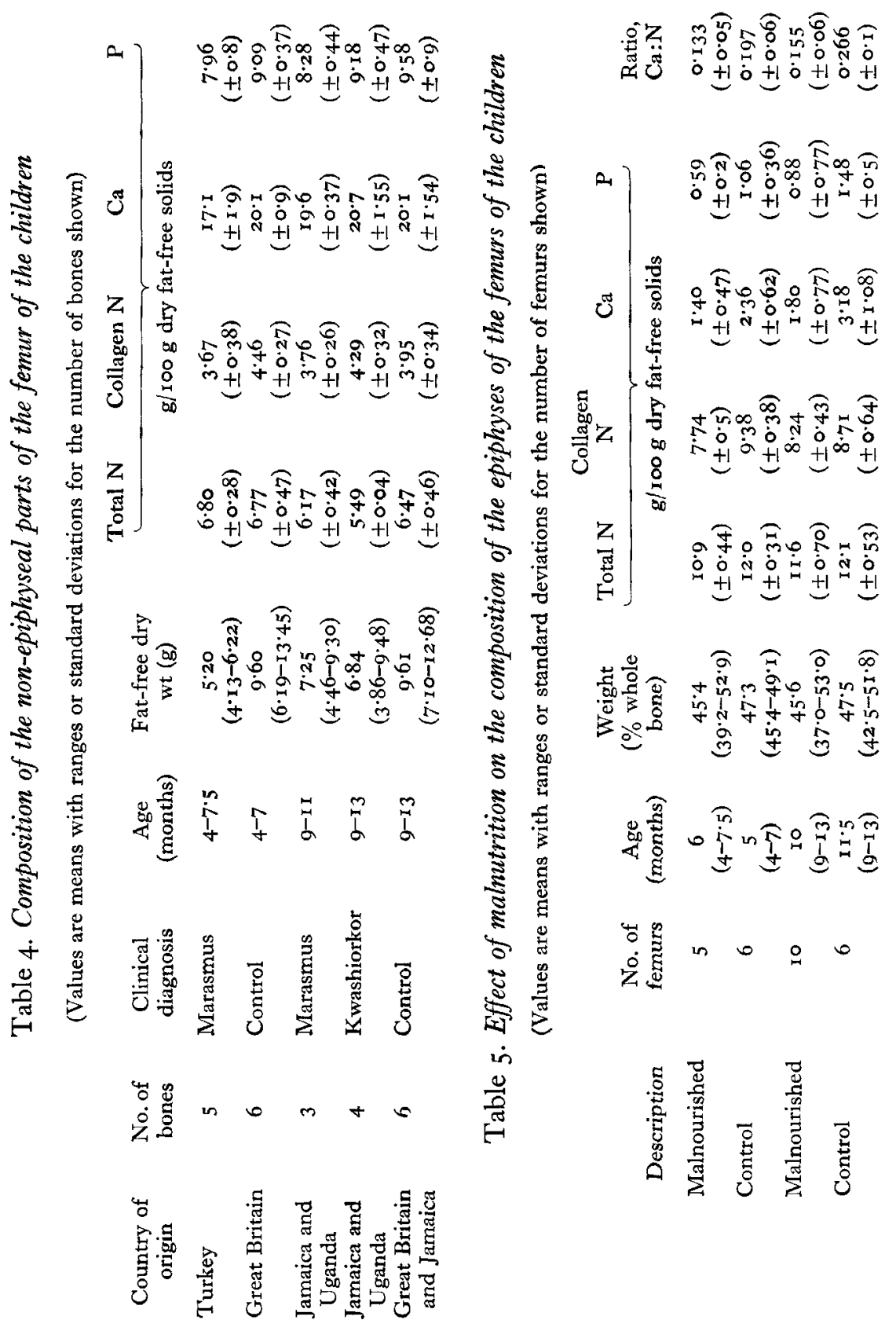


malnourished children. Moreover, the difference in length $(0.9 \mathrm{~cm})$ of the femurs of the two control groups was not as large as might be expected for the mean difference in age of 6.5 months. It seems reasonable to assume that the control bones in the older groups were short for their age. The small number of bones analysed precludes any speculation as to the reason for the discrepancy between the differences in body length and femur length.

Table 6. Composition of the cortex of the femurs of the children

(Values are means with ranges or standard deviations for the number of femurs shown)

\begin{tabular}{|c|c|c|c|c|c|c|c|c|c|}
\hline \multirow[b]{2}{*}{ Description } & \multirow{2}{*}{$\begin{array}{l}\text { No. of } \\
\text { femurs }\end{array}$} & \multirow{2}{*}{$\begin{array}{c}\text { Age } \\
\text { (months) }\end{array}$} & Total N & $\mathrm{CN}$ & $\mathrm{Ca}$ & $\mathrm{P}$ & \multirow{2}{*}{$\frac{\mathrm{CN} \times \text { I0o }}{\text { total } \mathrm{N}}$} & \multirow{2}{*}{$\begin{array}{l}\text { Ratio, } \\
\text { Ca:N }\end{array}$} & \multirow{2}{*}{$\begin{array}{l}\text { Ratio, } \\
\mathrm{Ca}: \mathrm{CN}\end{array}$} \\
\hline & & & \multicolumn{4}{|c|}{$\mathrm{g} /$ roo g dry fat-free solids } & & & \\
\hline Malnourished & 5 & $\begin{array}{c}6 \\
(4-7 \cdot 5)\end{array}$ & $\begin{array}{c}4.82 \\
( \pm 0.37)\end{array}$ & $\begin{array}{c}3.82 \\
( \pm 0.32)\end{array}$ & $\begin{array}{c}23 \cdot 3 \\
( \pm 2 \cdot 03)\end{array}$ & $\begin{array}{c}10 \cdot 0 \\
( \pm 0 \cdot 30)\end{array}$ & $\begin{array}{c}79 \cdot 3 \\
( \pm 4 \cdot 08)\end{array}$ & $\begin{array}{c}4.85 \\
( \pm 0.36)\end{array}$ & $6 \cdot 11$ \\
\hline Control & 6 & $\begin{array}{c}5 \\
(4-7)\end{array}$ & $\begin{array}{c}5.33 \\
( \pm 0 \cdot 27)\end{array}$ & $\begin{array}{c}4.5 x \\
( \pm 0 \cdot 18)\end{array}$ & $\begin{array}{c}24 \cdot 6 \\
( \pm 0 \cdot 7)\end{array}$ & $\begin{array}{c}11 \cdot 0 \\
( \pm 0 \cdot 32)\end{array}$ & $\begin{array}{c}84.7 \\
( \pm 4.35)\end{array}$ & $\begin{array}{c}4 \cdot 63 \\
( \pm 0 \cdot 28)\end{array}$ & $\begin{array}{c}5.46 \\
( \pm 0.32)\end{array}$ \\
\hline Malnourished & 10 & $\begin{array}{c}\text { I0 } \\
(9-13)\end{array}$ & $\begin{array}{c}5.06 \\
( \pm 0.50)\end{array}$ & $\begin{array}{c}4.00 \\
( \pm 0.22)\end{array}$ & $\begin{array}{c}23.9 \\
( \pm 0.9)\end{array}$ & $\begin{array}{c}10.4 \\
( \pm 0.65)\end{array}$ & $\begin{array}{c}79^{\circ} 9 \\
\left( \pm 7^{\circ} 8\right)\end{array}$ & $\begin{array}{c}4.8 I \\
( \pm 0.44)\end{array}$ & $\begin{array}{c}5.99 \\
( \pm 0.39)\end{array}$ \\
\hline Control & 6 & $\begin{array}{r}\mathrm{II} \cdot 5 \\
(9-13)\end{array}$ & $\begin{array}{c}5 \cdot 12 \\
( \pm 0 \cdot 17)\end{array}$ & $\begin{array}{c}4.01 \\
( \pm 0.23)\end{array}$ & $\begin{array}{c}24 \cdot 7 \\
( \pm 1 \cdot 0)\end{array}$ & $\begin{array}{c}I I \cdot I \\
( \pm 0 \cdot 35)\end{array}$ & $\begin{array}{c}78 \cdot 2 \\
( \pm 5 \cdot 0)\end{array}$ & $\begin{array}{c}4 \cdot 8 I \\
( \pm 0.26)\end{array}$ & $\begin{array}{c}5.92 \\
( \pm 0.57)\end{array}$ \\
\hline
\end{tabular}

Malnutrition results in a loss of bone tissue, the so-called bone atrophy (McLean \& Urist, 1961) or matrix osteoporosis (El Maraghi, Platt \& Stewart, 1965). The loss of bone tissue may be accompanied by hypercalcification of the thin cortex (Dickerson \& McCance, 196I) if the degree of undernutrition is very severe. Loss of bone tissue without hypercalcification of the cortex was found in the children's femurs. A similar thinning of the cortices has been found radiographically in the bones of the hands of malnourished children (Adams \& Berridge, 1969). The deficit in dry weight was apparently more severe in the children in the younger age-group and was accompanied by a significantly lower concentration of $\mathrm{Ca}$ in the bones.

Radiography of the knees has shown that skeletal maturation is retarded in malnourished children of about I year of age (Jones \& Dean, I959). The deficiency of $\mathrm{Ca}$ in the epiphyses of the femurs of children 9-I months of age is in agreement with these observations. In the epiphyses of the bones from malnourished children in the younger age-group there were lower concentrations of all the measured constituents than in those of controls of similar age. In the older age-group the differences were in the same direction but smaller. The sum of the measured constituents in the dry fat-free solids of the epiphyses of the bones of the malnourished children was therefore lower than the corresponding value for the bones of the control children. It is possible that the difference was caused by a higher concentration of mucopolysaccharides in the less highly calcified epiphyses of the malnourished children, for Bowness \& Jacobs (I968) have shown that the concentration of chondroitin sulphates in the rib falls during calcification.

There were no differences in the composition of the femur as a whole, the epiphyses, or the cortex that could be attributed specifically to marasmus or kwashiorkor. There 
was, however, a lower concentration of total $\mathrm{N}$ in the non-epiphyseal parts of the femurs of children with kwashiorkor than in either those with marasmus or in the control femurs. This deficiency in the bones from children with kwashiorkor was not due to a deficiency of collagen. The two possible causes of the deficiency in total $\mathrm{N}$ are a deficiency in the concentration of non-collagen $\mathrm{N}$ in the bone tissue or a deficiency of protein in the bone marrow. The second possibility seems to be the most likely one.

A high concentration of fat in the liver is characteristic of kwashiorkor. The absence of a correlation between the concentration of fat in the liver and that in the bone marrow suggests that fat metabolism in the two sites is different. In animals subjected to severe calorie deficiency from an early age, however, the liver, the bones and the body as a whole contain practically no fat (Dickerson \& McCance, 1964). It may be that the variable fat content in the bones is a reflection of the complexity of the problem that exists in most malnourished children.

We gratefully acknowledge the collaboration of those who sent us the material. These were Professor Cihit Tahain Gürson (Turkey), Dr M. Thorburn (Jamaica) and the late Professor R. F. A. Dean (Uganda). We would also like to thank Professor J. C. Waterlow, Professor R. A. McCance and Dr Elsie M. Widdowson for their encouragement and helpful criticisms.

\section{REFERENCES}

Adams, P. \& Berridge, F. R. (1969). Archs Dis. Childh. (In the Press.)

Berridge, F. R. \& Prior, K. M. (1954). Spec. Rep. Ser. med. Res. Coun. no. 287 , p. IIg.

Bowness, J. M. \& Jacobs, M. (1968). Can. F. Biochem. 46, 63.

Dickerson, J. W. T. (1962a). Biochem. F. 82, 56.

Dickerson, J. W. T. (1962b). Biochem. F. 82, 47.

Dickerson, J. W. T. \& Hughes, P. C. R. (I968). Proc. Nutr. Soc. 27, 43 A.

Dickerson, J. W. T. \& McCance, R. A. (1961). Br. Y. Nutr. 15, 567.

Dickerson, J. W. T. \& McCance, R. A. (1964). Clin. Sci. 27, I23.

Dickerson, J. W. T. \& Widdowson, E. M. (1960). Proc. R. Soc. B I52, 207.

El-Maraghi, N. R. H., Platt, B. S. \& Stewart, R. J. C. (r965). Br. F. Nutr. r9, 49 r.

Garrow, J. S. (1966). Lancet ii, 592.

Jelliffe, D. B. (1959). F. Pediat. 54, 227.

Jones, P. R. M. \& Dean, R. F. A. (I956). F. trop. Pediat. 2, 5 I.

Jones, P. R. M. \& Dean, R. F. A. (I959). F. Pediat. 54, I76.

McLaren, D. S. (1966). Lancet ii, 485 .

McLean, F. C. \& Urist, M. R. (196r). Bone, and ed. Chicago: University of Chicago Press.

Tanner, J. M., Whitehouse, R. H. \& Takaishi, M. (1966). Archs Dis. Childh. 41, 613. 